\title{
Sann-Joong-Kuey-Jian-Tang decreases the protein expression of Mcl-1 and TCTP and increases that of TNF- $\alpha$ and Bax in BxPC-3 pancreatic carcinoma cells
}

\author{
SU-YU CHIEN ${ }^{3 *}$, SHOU-JEN KUO ${ }^{2 *}$, DAR-REN CHEN ${ }^{2}$ and CHIN-CHENG SU ${ }^{1,2,4}$ \\ ${ }^{1}$ Tumor Research Center of Integrative Medicine, ${ }^{2}$ Comprehensive Breast Cancer Center, \\ ${ }^{3}$ Department of Pharmacy, Changhua Christian Hospital, Changhua 50006; ${ }^{4}$ School of Chinese Medicine, \\ College of Chinese Medicine, China Medical University, Taichung 40402, Taiwan, R.O.C.
}

Received February 19, 2013; Accepted April 25, 2013

DOI: 10.3892/ijmm.2013.1369

\begin{abstract}
Sann-Joong-Kuey-Jian-Tang (SJKJT), a traditional Chinese medicinal prescription, has been used for the treatment of lymphadenopathy and solid tumors, and has shown therapeutic potential in several human malignant tumor cell lines. However, the efficacy and molecular mechanisms of action of SJKJT in human pancreatic cancer have not yet been elucidated. In the present study, we evaluated the cytotoxic effects of SJKJT on BxPC-3 human pancreatic carcinoma cells by MTT assay. The protein expression levels of myeloid cell leukemia 1 protein (Mcl-1), translationally controlled tumor protein (TCTP), tumor necrosis factor- $\alpha$ (TNF- $\alpha$ ), caspase- 8 , caspase-3, Bax and Bcl-2 family in the BxPC-3 cells were measured by western blot analysis. The cell cycle was analyzed by flow cytometry. The protein expression of caspase- 3 was also detected by immunocytochemistry (ICC). The results revealed that SJKJT inhibited the proliferation of BxPC-3 cells in a time- and dose-dependent manner. The protein expression levels of TNF- $\alpha$, caspase- 8 , caspase- 3 and Bax increased in the BxPC-3 cells treated with SJKJT; however, the levels of Mcl-1, TCTP and Bcl-xL decreased. The results also demonstrated that SJKJT increased the percentage of BxPC-3 cells in the sub-G1 phase. In addition, ICC staining indicated that the protein expression of caspase- 3 was upregulated in the BxPC-3 cells treated with SJKJT. These findings indicate that SJKJT inhibits the proliferation of BxPC-3 cells through the extrinsic and intrinsic pathway, inducing apoptosis in vitro. Our study, using BxPC-3 human pancreatic cancer cells, demonstrates
\end{abstract}

Correspondence to: Dr Chin-Cheng Su, Tumor Research Center of Integrative Medicine, Comprehensive Breast Cancer Center, Changhua Christian Hospital, 135 Nan-Hsiao Street, Changhua 50006, Taiwan, R.O.C.

E-mail: succ.maeva@msa.hinet.net

*Contributed equally

Key words: Sann-Joong-Kuey-Jian-Tang, BxPC-3 cells, myeloid cell leukemia 1 protein, translationally controlled tumor protein, tumor necrosis factor- $\alpha$, Bax that SJKJT has potential as a chemotherapeutic agent for the treatment of pancreatic cancer. Further sutdies are warranted to fully elucidate its mechanisms of action.

\section{Introduction}

Pancreatic cancer is the fourth leading cause of cancer-related mortality in the US $(1,2)$. Although many efforts have been made to improve the clinical treatment of this disease, pancreatic cancer remains a challenging malignancy (3-5). Due to the fact that the majority of diagnoses are made during the late stages of disease and poor response to current chemotherapeutic medicine (such as gemcitabine), the 1-year survival rate is only $18 \%$ and the overall 5 -year survival rate is 3-5\% (6,7). Sann-Joong-Kuey-Jian-Tang (SJKJT), a traditional Chinese medicinal prescription, consists of 17 species of medicinal herbs: Phellodendron amurense Rupr., Glycyrrhiza uralensis Fisch, Sparganium stoloniferum Buch., Curcuma aeruginosa Roxb., Laminaria japonica Aresch, Bupleurum scorzoneri folium Willd (Bupleurum chinense DC), Coptis chinensis Franch, Angelica sinensis Diels, Cimicifuga heracleifolia Komar, Trichosanthes cucumeroides Maxim, Anemarrhena asphodeloides Bunge, Scutellaria baicalensis Georgi, Gentiana scabra Bunge, Platycodon grandiflorus, Forsythia suspensa Vahl, Paeonia lactiflora Pall and Pueraria lobata Ohwi. It has been shown to inhibit the proliferation of human breast cancer cells by blocking cell cycle progression and inducing apoptosis (8). It has been documented that SJKJT does not exert significant toxic effects on certain types of normal cells (9). In our previous studies, we showed that SJKJT inhibited the proliferation of colo 205 human colon cancer cells by increasing the protein expression of microtubule-associated protein II light chain 3 (LC3-II) in vitro (10). SJKJT increased the protein expression levels of tumor necrosis factor- $\alpha$ (TNF- $\alpha$ ), caspase- 8 and caspase-3 in colo 205, inducing apoptosis in vitro and in vivo (11). SJKJT has been prescribed as complementary medicine for patients with solid tumors in Taiwan. In a recent study of ours, we showed that SJKJT inhibited the proliferation of Hep-G2 hepatocellular carcinoma cells by increasing TNF- $\alpha$, caspase- 8 , caspase- 3 and Bax expression and decreasing translationally controlled tumor protein (TCTP) and myeloid cell leukemia 1 protein (Mcl-1) expression in vitro (12). However, the 
anticancer effects of SJKJT on human pancreatic cancer have not yet been elucidated. The present study focused on the anticancer effects and molecular mechanisms of action of SJKJT in human pancreatic cancer, using BxPC-3 human pancreatic cancer cells.

\section{Materials and methods}

Crude extract of SJKJT was obtained from Chuang Song Zong Pharmaceutical Co.,Ltd.(Ligang Shiang, Taiwan). The BxPC-3 human pancreatic cancer cell line (BCRC no. 60283) was obtained from the Food Industry Research and Development Institute (Hsinchu, Taiwan). Potassium phosphate and TE buffer were purchased from Merck Co. (Darmstadt, Germany). Fetal bovine serum (FBS) and glutamine were from Gibco-BRL (Grand Island, NY, USA). 3-(4,5-Dimethylthiazol-2-y1)-2,5diphenyltetrazolium bromide (MTT), sodium deoxycholate, leupeptin, Triton X-100, Tris- $\mathrm{HCl}$, ribonuclease-A and sodium pyruvate, HEPES, dimethyl sulfoxide (DMSO) and RPMI1640 were from Sigma-Aldrich (St. Louis, MO, USA). Mouse anti- $\beta$-actin, and penicillin-streptomycin were obtained from Sigma-Aldrich. BioMax film was from Kodak. The antibodies used were antibodies against: Bax (no. 2774), Bcl-xL (no. 2764), Mcl-1 (no. 2764), TCTP (no. 2764), caspase-8 (no. 9502) and TNF- $\alpha$ (no. 3707) (all from Cell Signaling Technology, Beverly, MA, USA); as well as antibodies against caspase-3 (Lot: NB500-210) (Novus Biologicals, LLC, Littleton, CO, USA); other materials and reagents not specified were obtained from Sigma-Aldrich or Merck.

Cell culture. The BxPC-3 cells obtained from the Food Industry Research and Development Institute, were maintained in RPMI-1640 medium containing 10\% FBS, 1\% penicillin/ streptomycin (10,000 U/ml penicillin, $10 \mathrm{mg} / \mathrm{ml}$ streptomycin) at $37^{\circ} \mathrm{C}$ in a humidified atmosphere containing $5 \% \mathrm{CO}_{2}$.

Cytotoxicity assay. The BxPC-3 cells were plated in 96-well plates at a density of $1 \times 10^{4}$ cells/well for $16-20 \mathrm{~h}$, and treated with various concentrations $(0,0.1,0.2,0.4,0.6,0.8$ and $1 \mathrm{mg} / \mathrm{ml})$ of SJKJT for different periods of time (24, 48 and $72 \mathrm{~h}$ ). The cells were then incubated with $1 \mathrm{mg} / \mathrm{ml}$ of MTT in fresh RPMI-1640 medium for $2 \mathrm{~h}$. The surviving cells were measured at $590 \mathrm{~nm}$ using a microplate reader. The relative percentage of cell viability was calculated by dividing the absorbance of the treated cells by that of the control cells in each experiment, using the following formula: proliferation rate $(\%)=($ OD test - OD blank) $x 100$, where OD test and OD blank are the optical density of the test substances and the blank control, respectively.

Cell cycle analysis. BxPC-3 cells were treated with various concentrations $(0,0.3,0.6$ and $1.2 \mathrm{mg} / \mathrm{ml})$ of SJKJT for $48 \mathrm{~h}$ or with various concentrations $(0,0.1,0.3$ and $0.6 \mathrm{mg} / \mathrm{ml})$ of SJKJT for $72 \mathrm{~h}$, and were then collected and fixed with ice-cold ethanol ( $70 \%$ ) overnight at $-20^{\circ} \mathrm{C}$; the cell pellets were then treated with propidium iodide (PI) solution (containing $100 \mu \mathrm{g} / \mathrm{ml}$ RNase) for $30 \mathrm{~min}$ at $37^{\circ} \mathrm{C}$. Subsequently, the samples were analyzed using a Cytomics TM FC 500 flow cytometer (Beckman Coulter Inc., Brea, CA, USA). A minimum of 10,000 cells was analyzed for DNA content, and the percentage of cells in each cell cycle phase was quantified.
Immunocytochemistry (ICC). BxPC-3 cells were treated with various concentrations $(0,0.3,0.6$ and $1.2 \mathrm{mg} / \mathrm{ml})$ of SJKJT for $48 \mathrm{~h}$ or with various concentrations $(0,0.1,0.3$ and $0.6 \mathrm{mg} / \mathrm{ml})$ of SJKJT for $72 \mathrm{~h}$ and were then washed with PBS. Following fixation with $50 \%$ acetone and $50 \%$ methanol solution overnight at $4^{\circ} \mathrm{C}$, the cells were washed 3 times with PBS, and non-specific binding sites were blocked in PBS containing $0.1 \%$ BSA for $1 \mathrm{~h}$ at room temperature. Thereafter, the cells were separately incubated with rabbit anti-caspase-3 (1:20) antibody in PBS containing $0.1 \% \mathrm{BSA}$ overnight at $4^{\circ} \mathrm{C}$, and washed 3 times with PBS. They were then incubated with anti-rabbit FITC antibody (1:200) in PBS containing 0.1\% BSA for $1 \mathrm{~h}$ at room temperature, and washed 3 times with PBS. The nuclei were stained with $5 \mu \mathrm{g} / \mathrm{ml}$ PI. After staining, the samples were immediately examined under an Olympus IX81 microscope (Olympus, Tokyo, Japan).

Western blot analysis. The effects of SJKJT on the protein expression levels of TNF- $\alpha$, caspase-8, Bax, caspase-3, Mcl-1, TCTP and Bcl-xL in the BxPC-3 cells were examined by western blot analysis. The BxPC-3 cells were treated with various concentrations $(0,0.3,0.6$ and $1.2 \mathrm{mg} / \mathrm{ml})$ of SJKJT for $48 \mathrm{~h}$ or with various concentrations $(0,0.1,0.3$ and $0.6 \mathrm{mg} / \mathrm{ml})$ of SJKJT for $72 \mathrm{~h}$, and the protein expression levels of TNF- $\alpha$, caspase-8, Bax, caspase-3, Mcl-1, TCTP and Bcl-xL were then evaluated by western blot analysis. The procedure was follows: following treatment with the drug, the cells were lysed on ice-cold whole cell extract buffer containing protease inhibitors. The lysate was then vibrated for $30 \mathrm{~min}$ at $4^{\circ} \mathrm{C}$ and centrifuged at $10,000 \mathrm{rpm}$ for $10 \mathrm{~min}$. The protein concentration was measured using the BCA protein assay kit (Pierce, Rockford, IL, USA). Equal amounts of protein were subjected to electrophoresis using $12 \%$ sodium dodecyl sulfate-polyacrylamide gels. To verify equal protein loading and transfer, the proteins were then transferred onto polyvinylidene difluoride membranes and the membranes were blocked overnight at $4{ }^{\circ} \mathrm{C}$ using blocking buffer [5\% non-fat dried milk in solution containing $50 \mathrm{mM}$ Tris/ $\mathrm{HCl}$ (pH 8.0), $2 \mathrm{mM} \mathrm{CaCl}_{2}$, $80 \mathrm{mM}$ sodium chloride, $0.05 \%$ Tween-20 and $0.02 \%$ sodium azide]. The membranes were then incubated for $2 \mathrm{~h}$ at $25^{\circ} \mathrm{C}$ with specific primary antibody followed by anti-rabbit or antimouse immunoglobulin G-horseradish peroxidase conjugated secondary antibodies. The membranes were washed 3 times for $10 \mathrm{~min}$ with washing solution. Finally, the protein bands were visualized on X-ray film using the enhanced chemiluminescence detection system (PerkinElmer Life and Analytical Sciences, Boston, MA, USA).

Statistical analysis. Values are presented as the means \pm SD. The Student's t-test was used to analyze statistical significance. A P-value $<0.05$ was considered to indicate a statistically significant difference for all the tests.

\section{Results and Discussion}

Effects of SJKJT on the viability of BxPC-3 cells. The results revealed that SJKJT inhibited the proliferation of $\mathrm{BxPC}-3$ cells in a time- and dose-dependent manner. The half-maximal inhibitory concentration $\left(\mathrm{IC}_{50}\right)$ was $1.38,0.59$ and $0.26 \mathrm{mg} / \mathrm{ml}$ at 24,48 and $72 \mathrm{~h}$, respectively (Fig. 1). 


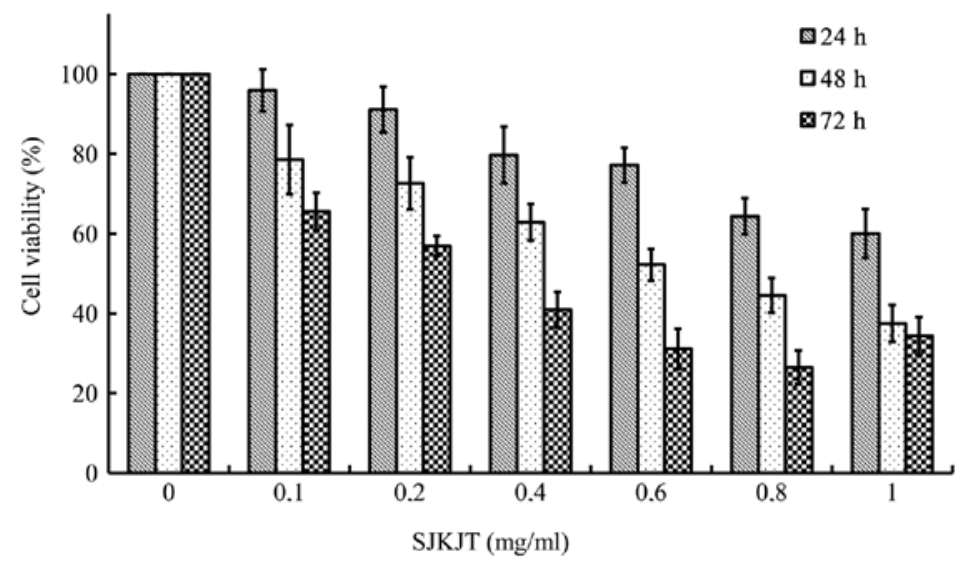

Figure 1. Cytotoxic effects of Sann-Joong-Kuey-Jian-Tang (SJKJT) on BxPC-3 cells. The cytotoxic effects of SJKJT on BxPC-3 cells was determined by MTT assay as described in Materials and methods. Each point is the mean \pm SD of 3 experiments.

A $48 \mathrm{~h}$

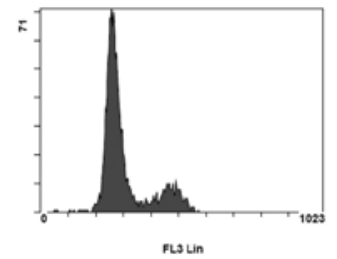

control

$72 \mathrm{~h}$

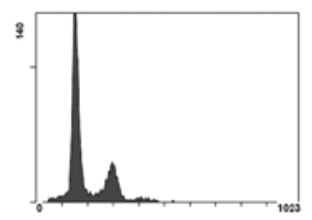

control

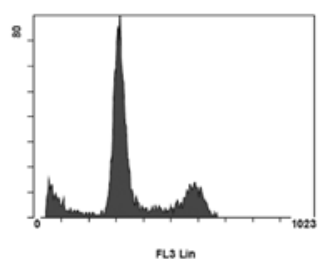

$0.3(\mathrm{mg} / \mathrm{ml})$

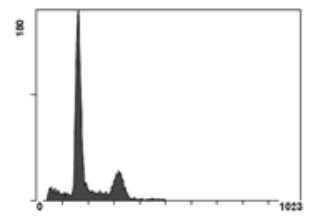

$0.1(\mathrm{mg} / \mathrm{ml})$

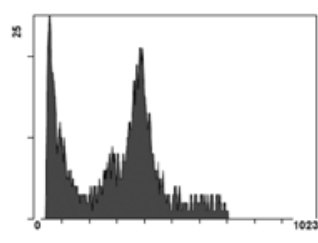

roun

$0.6(\mathrm{mg} / \mathrm{ml})$

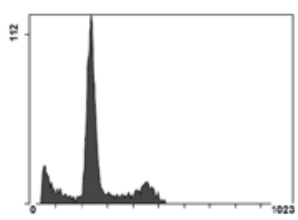

$0.3(\mathrm{mg} / \mathrm{ml})$

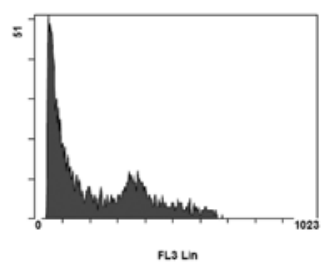

$1.2(\mathrm{mg} / \mathrm{ml})$

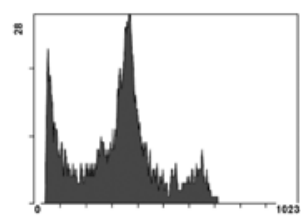

$0.6(\mathrm{mg} / \mathrm{ml})$
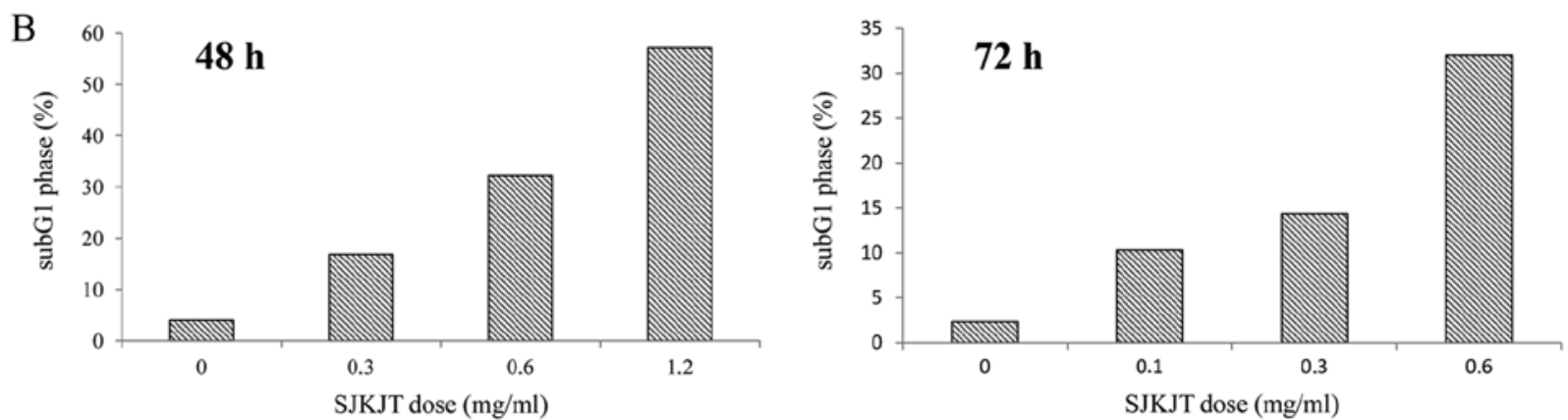

Figure 2. Effect of Sann-Joong-Kuey-Jian-Tang (SJKJT) on the cell cycle in BxPC-3 cells. BxPC-3 cells were plated in 6-cm dish and were then treated with various concentrations of SJKJT for different periods of time (48 and $72 \mathrm{~h}$ ). (A) The cell cycle was analyzed by FACS as described in Materials and methods. When the BxPC-3 cells were cultured with various concentrations $(0,0.3,0.6$ and $1.2 \mathrm{mg} / \mathrm{ml})$ of SJKJT for $48 \mathrm{~h}$, the percentage of cells in the subG1 phase was $3.97,16.87,32.2$ and $57.13 \%$, respectively. (B) When the BxPC-3 cells were cultured with various concentrations (0, $0.1,0.3$ and $0.6 \mathrm{mg} / \mathrm{ml})$ of SJKJT for $72 \mathrm{~h}$, the percentage of cells in the sub-G1 phase was $2.33,10.33,14.37$ and $32.06 \%$, respectively.

SJKJT induces the apoptosis of BxPC-3 cells. The BxPC-3 cells were plated in 6-cm dish at a density of $1 \times 10^{6}$ cells/dish and were then treated with various concentrations of SJKJT for different periods of time ( 48 and $72 \mathrm{~h}$ ). The cell cycle was analyzed by FACS. When the BxPC-3 cells were cultured with various concentrations $(0,0.3,0.6$ and $1.2 \mathrm{mg} / \mathrm{ml})$ of SJKJT for $48 \mathrm{~h}$, the percentage of cells in the subG1 phase was 3.97, 16.87, 32.2 and $57.13 \%$, respectively. When the BxPC-3 cells were cultured with various concentrations $(0,0.1,0.3$ and $0.6 \mathrm{mg} / \mathrm{ml})$ of SJKJT for $72 \mathrm{~h}$, the percentage of cells in the sub-G1 phase was $2.33,10.33$, 14.37 and $32.06 \%$, respectively (Fig. 2). These results demonstrated that treatment of the BxPC- 3 cells with SJKJT increased 

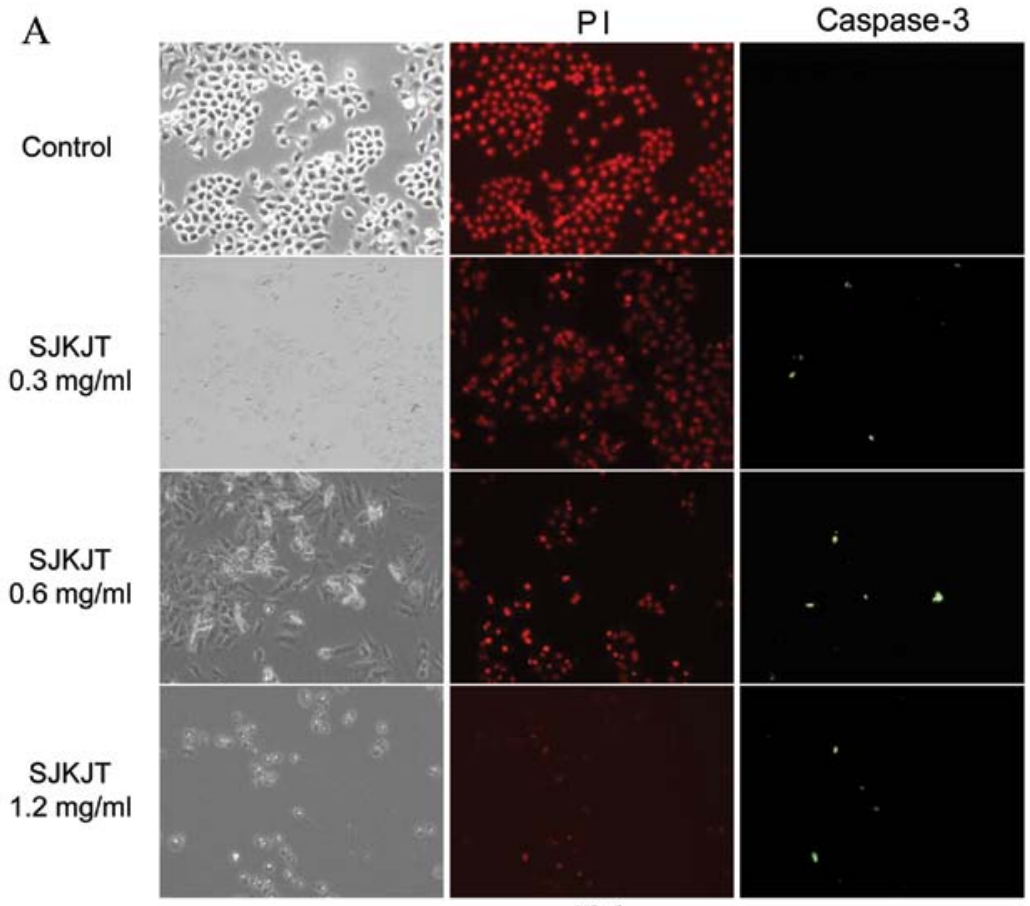

$48 \mathrm{~h}$
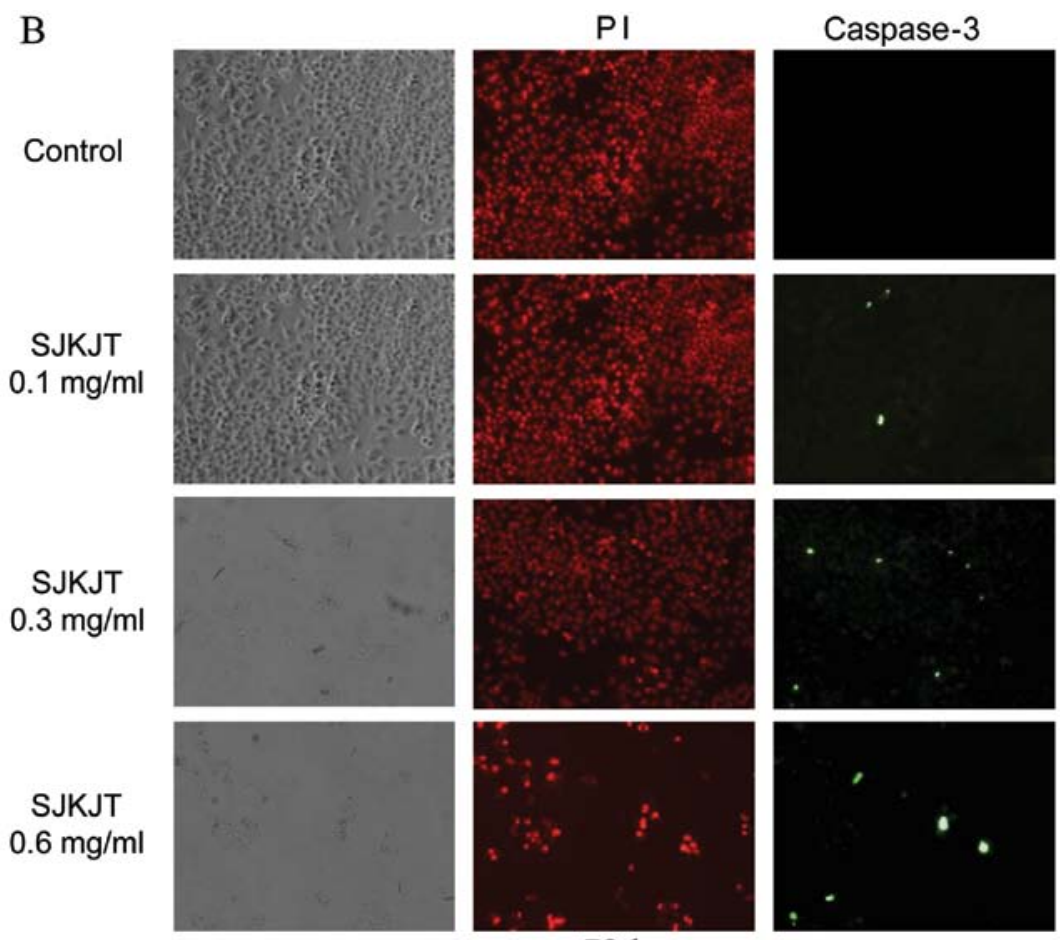

$72 \mathrm{~h}$

Figure 3. Protein expression of caspase-3 in BxPC-3 cells as shown by immunocytochemical analysis. BxPC-3 cells were treated with various concentrations of $\operatorname{SJKJT}(0,0.3,0.6$ and $1.2 \mathrm{mg} / \mathrm{ml})$ for $48 \mathrm{~h}$ or with various concentrations of SJKJT $(0,0.1,0.3$ and $0.6 \mathrm{mg} / \mathrm{ml})$ for $72 \mathrm{~h}$, then immunocytochemical analysis was performed as described in Materials and methods. (A and B) The results revealed that SJKJT increased caspase-3 expression in BxPC-3 cells. These findings also suggest that SJKJT induces the apoptosis of BxPC-3 cells in vitro.

the percentage of cells in the subG1 phase. This indicates that SJKJT induces the apoptosis of BxPC- 3 cells.

ICC analysis. The BxPC-3 cells were treated with various concentrations of SJKJT $(0,0.3,0.6$ and $1.2 \mathrm{mg} / \mathrm{ml})$ for $48 \mathrm{~h}$ or with various concentrations of SJKJT $(0,0.1,0.3$ and $0.6 \mathrm{mg} / \mathrm{ml})$ for $72 \mathrm{~h}$; the cells were then fixed with $4 \%$ paraformaldehyde for the detection of the protein expression of caspase- 3 . The results revealed that SJKJT increased caspase-3 expression in a dose-dependent manner in the BxPC-3 cells (Fig. 3). These findings also suggest that SJKJT induces the apoptosis of BxPC-3 cells in vitro. 

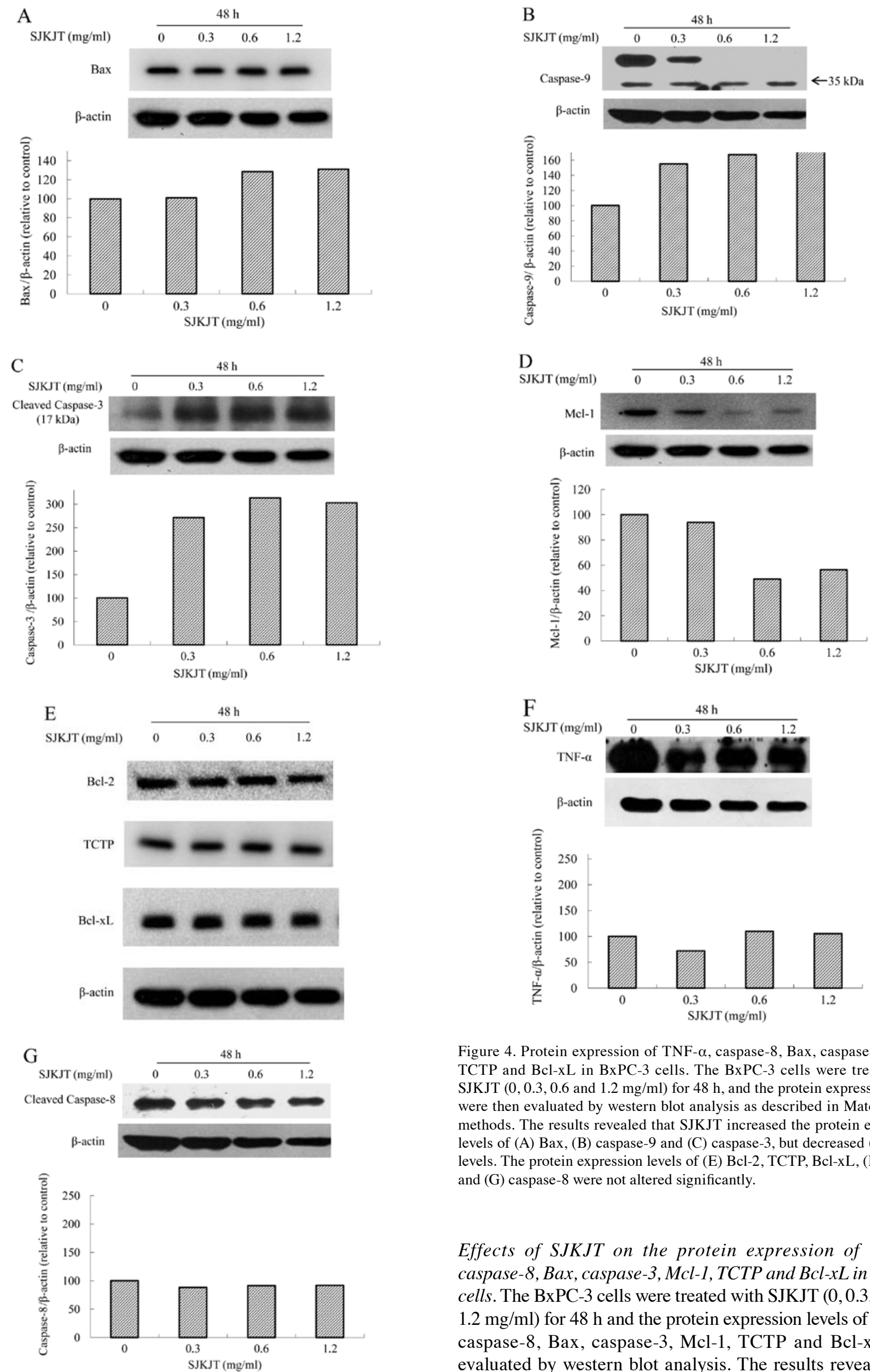

Figure 4. Protein expression of TNF- $\alpha$, caspase-8, Bax, caspase-3, Mcl-1, TCTP and Bcl-xL in BxPC-3 cells. The BxPC-3 cells were treated with SJKJT $(0,0.3,0.6$ and $1.2 \mathrm{mg} / \mathrm{ml})$ for $48 \mathrm{~h}$, and the protein expression levels were then evaluated by western blot analysis as described in Materials and methods. The results revealed that SJKJT increased the protein expression levels of (A) Bax, (B) caspase-9 and (C) caspase-3, but decreased (D) Mcl-1 levels. The protein expression levels of (E) Bcl-2, TCTP, Bcl-xL, (F) TNF- $\alpha$ and $(\mathrm{G})$ caspase- 8 were not altered significantly.

Effects of SJKJT on the protein expression of TNF- $\alpha$, caspase-8, Bax, caspase-3, Mcl-1, TCTP and Bcl-xL in BxPC-3 cells. The BxPC-3 cells were treated with SJKJT $(0,0.3,0.6$ and $1.2 \mathrm{mg} / \mathrm{ml}$ ) for $48 \mathrm{~h}$ and the protein expression levels of TNF- $\alpha$, caspase-8, Bax, caspase-3, Mcl-1, TCTP and Bcl-xL were evaluated by western blot analysis. The results revealed that 

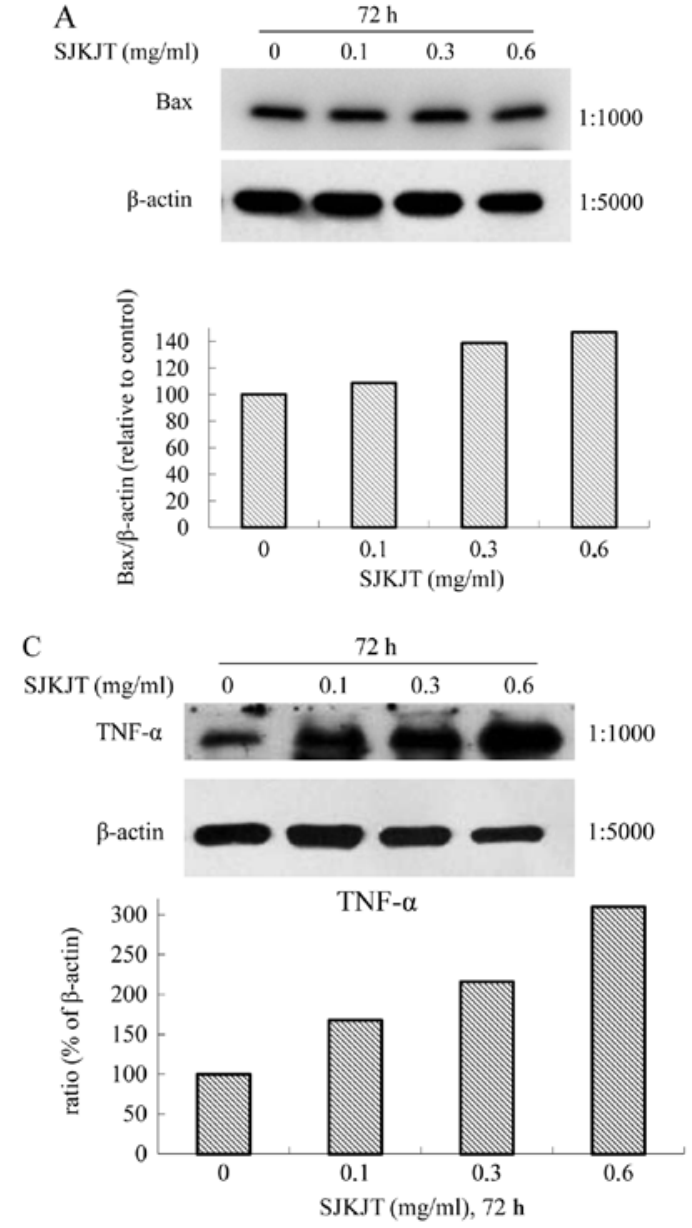

$\mathrm{E}$
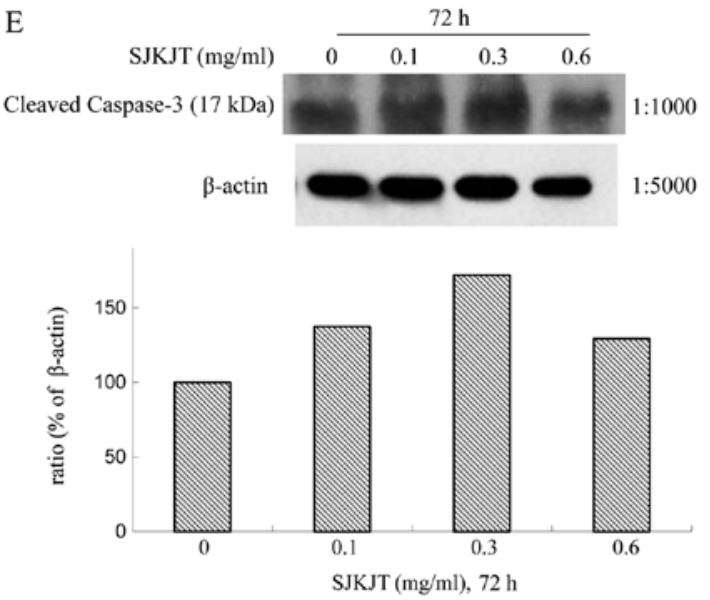

G

$\begin{array}{lllll}\text { SJKJT }(\mathrm{mg} / \mathrm{ml}) & 0 & 0.1 & 0.3 & 0.6\end{array}$

Bcl-2

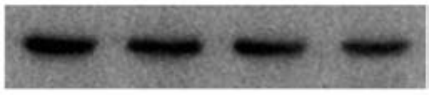

Bcl-xL

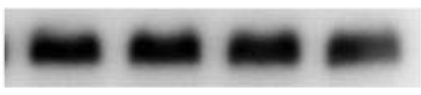

TCTP

$\beta$-actin

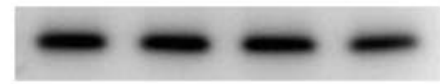

B
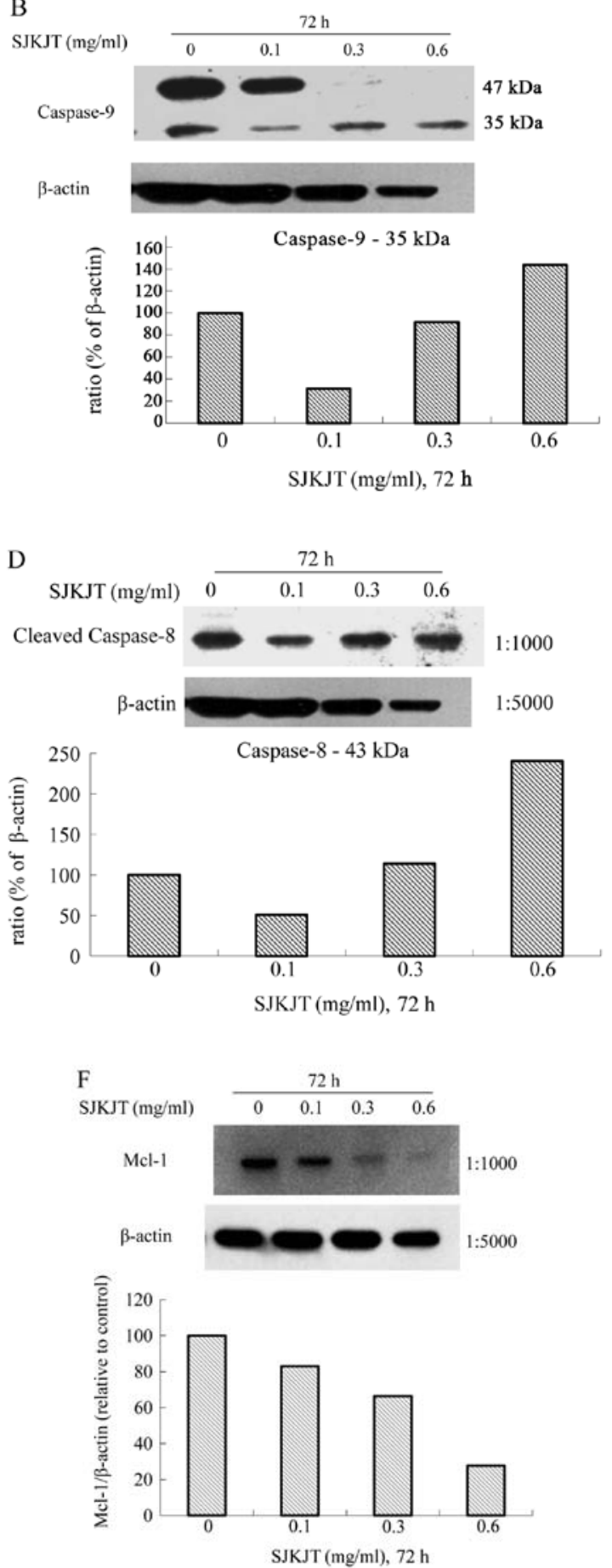

Figure 5.Protein expression of TNF- $\alpha$, caspase-8, Bax, caspase-3, Mcl-1, TCTP and Bcl-xL in BxPC-3 cells. The BxPC-3 cells were treated with SJKJT $(0,0.1,0.3$ and $0.6 \mathrm{mg} / \mathrm{ml})$ for $72 \mathrm{~h}$, and the protein expression levels were then evaluated by western blot analysis as described in Materials and methods. The results revealed that SJKJT increased the protein expression levels of (A) Bax, (B) caspase-9, (C) TNF- $\alpha$, (D) caspase-8 and (E) caspase-3, but decreased (F) Mcl-1, (G) Bcl-2, Bcl-xl and TCTP levels.

SJKJT increased the protein expression levels of Bax (Fig. 4A), caspase-9 (Fig. 4B) and caspase-3 (Fig. 4C), but decreased Mcl-1 (Fig. 4D) levels. The protein expression levels of Bcl-2, TCTP, Bcl-xL (Fig. 4E), TNF- $\alpha$ (Fig. 4F) and caspase-8 (Fig. 4G) were not altered significantly. The BxPC-3 cells were then treated with SJKJT $(0,0.1,0.3$ and $0.6 \mathrm{mg} / \mathrm{ml})$ for $72 \mathrm{~h}$. The results 


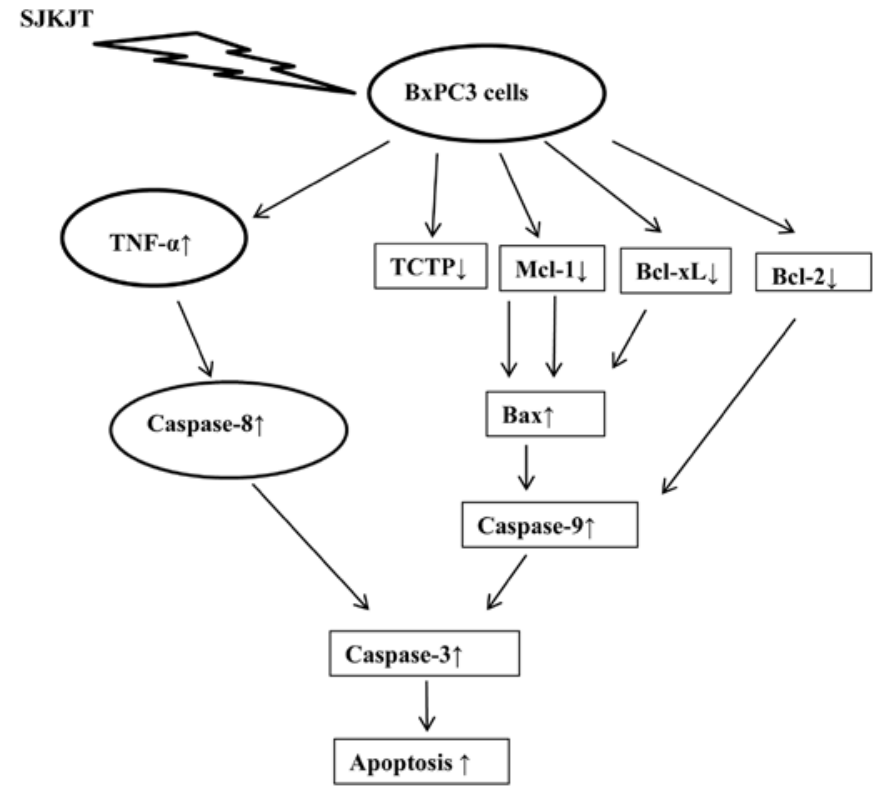

Figure 6. The proposed signaling pathway through which Sann-Joong-KueyJian-Tang (SJKJT) exerts its anti-proliferative effects on BxPC-3 human pancreatic cancer cells.

revealed that SJKJT increased the protein expression levels of Bax (Fig. 5A), caspase-9 (Fig. 5B), TNF- $\alpha$ (Fig. 5C), caspase-8 (Fig. 5D) and caspase-3 (Fig. 5E), but decreased Mcl-1 (Fig. 5F), Bcl-2, Bcl-xL and TCTP levels (Fig. 5G).

It has been well documented that TNF- $\alpha$ binds to TNF receptor type 1 , resulting in the activation of caspase- 8 and caspase-3, thus inducing apoptosis $(13,14)$. Our results demonstrated that the treatment of BxPC-3 cells with SJKJT increased the protein expression levels of TNF- $\alpha$, caspase- 8 and caspase-3. These findings indicate that one of the molecular mechanisms of action of SJKJT involved in the inhibition of BxPC-3 human pancreatic cancer cell proliferation may be through the extrinsic pathway.

TCTP is a hydrophilic protein, widely expressed in all eukaryotic organisms. It was discovered in Ehrlich ascites tumor cells, and has been implicated in the protection of cells against various stress conditions and apoptosis (15-18). It has been well documented that TCTP binds to Bcl-xL and Mcl-1, antagonizing Bax, and thus inhibiting the induction of apoptosis (19-22). Our results demonstrated that the treatment of BxPC-3 cells with SJKJT decreased the protein expression levels of Mcl-1, Bcl-xL and TCTP, but increased Bax, caspase-9 and caspase-3 levels. Our results also indicated that SJKJT induced the apoptosis of BxPC-3 cells. Therefore, one of the molecular mechanisms of action of SJKJT involved in the inhibition of BxPC-3 human pancreatic cancer cell proliferation may be through the downregulation of Mcl-1, Bcl-xL and TCTP, and the upregulation of Bax and caspase- 9 protein expression, thus inducing apoptosis.

The results of present study, using BxPC-3 human pancreatic cancer cells, demonstrate that SJKJT has potential as a therapeutic agent for the treatment of pancreatic cancer in vitro. One of the molecular mechanisms behind the antiproliferative effects of SJKJT may through the intrinsic pathway; another may be through the extrinsic pathway. The proposed signaling pathway through which SJKJT exerts its anti-proliferative effects on BxPC-3 human pancreatic cancer cells is shown in Fig. 6. To our knowledge, this is the first report to demonstrate that SJKJT inhibits the proliferation of BxPC-3 human pancreatic cancer cells. Further sutdies are warranted to fully elucidate its mechanisms of action.

\section{Acknowledgements}

The present study was supported by a grant (100-CCHICO-06-1) from the Changhua Christian Hospital, Changhua, Taiwan, R.O.C.

\section{References}

1. Siegel R, Ward E, Brawley O and Jemal A: Cancer statistics, 2011: the impact of eliminating socioeconomic and racial disparities on premature cancer deaths. CA Cancer J Clin 61: 212-236, 2011.

2. Siegel R, Naishadham D and Jemal A: Cancer statistics, 2012: CA Cancer J Clin 62: 10-29, 2012.

3. Louvet C, Labianca R, Hammel P, et al: Gemcitabine in combination with oxaliplatin compared with gemcitabine alone in locally advanced or metastatic pancreatic cancer: results of a GERCOR and GISCAD phase III trial. J Clin Oncol 23: 3509-3516, 2005.

4. Heinemann V, Quietzsch D, Gieseler F, et al: Randomized phase III trial of gemcitabine plus cisplatin compared with gemcitabine alone in advanced pancreatic cancer. J Clin Oncol 24: 3946-3952, 2006.

5. Herrmann R, Bodoky G, Ruhstaller T et al: Gemcitabine plus capecitabine compared with gemcitabine alone in advanced pancreatic cancer: a randomized, multicenter, phase III trial of the Swiss Group for Clinical Cancer Research and the Central European Cooperative Oncology Group. J Clin Oncol 25: 2212-2217, 2007

6. Burris HA III, Moore MJ, Andersen J, et al: Improvements in survival and clinical benefit with gemcitabine as first-line therapy for patients with advanced pancreas cancer: a randomized trial. J Clin Oncol 15: 2403-2413, 1997.

7. Wang Z, Li Y, Ahmad A, Banerjee S, Azmi AS, Kong D and Sarkar FH: Pancreatic cancer: understanding and overcoming chemoresistance. Nat Rev Gastroenterol Hepatol 8: 27-33, 2011.

8. Hsu YL, Yen MH, Kuo PL et al: San-Zhong-Kui-Jian-Tang, a traditional Chinese medicine prescription, inhibits the proliferation of human breast cancer cells by blocking cell cycle progression and inducing apoptosis. Biol Pharm Bull 29: 2388-2394, 2006.

9. Yang $\mathrm{CH}$ and Craise LM: Development of human epithelial cell systems for radiation risk assessment. Adv Space Res 14: 115-120, 1994.

10. Cheng CY, Lin YH and Su CC: Sann-Joong-Kuey-Jian-Tang increases the protein expression of microtubule-associated protein II light chain 3 in human colon cancer colo 205 cells. Mol Med Rep 2: 707-711, 2009.

11. Cheng CY, Lin YH and Su CC: Sann-Joong-Kuey-Jian-Tang up-regulates the protein expression of Fas and TNF- $\alpha$ in colo 205 cells in vivo and in vitro. Mol Med Rep 3: 63-67, 2010.

12. Chen YL, Yan MY, Chien SY, Kuo SJ, Chen DR, Cheng CY and Su CC: Sann-Joong-Kuey-Jian-Tang inhibits hepatocellular carcinoma Hep-G2 cell proliferation by increasing TNF- $\alpha$, Caspase- 8 , Caspase- 3 and Bax but by decreasing TCTP and Mcl-1 expression in vitro. Mol Med Rep 7: 1487-1493, 2013.

13. Carswell EA, Old LJ, Kassel RL, et al: An endotoxin-induced serum factor that causes necrosis of tumors. Proc Natl Acad Sci USA 72: 3666-3670, 1975.

14. Gaur U and Aggarwal BB: Regulation of proliferation, survival and apoptosis by members of the TNF superfamily. Biochem Pharmacol 66: 1403-1408, 2003.

15. Yenofsky R, Cereghini S, Krowczynska A and Brawerman G: Regulation of mRNA utilization in mouse erythroleukemia cells induced to differentiate by exposure to dimethyl sulfoxide. Mol Cell Biol 3: 1197-1203, 1983.

16. Chitpatima ST,Makrides S, Bandyopadhyay R and Brawerman G: Nucleotide sequence of a major messenger RNA for a 21 kilodalton polypeptide that is under translational control in mouse tumor cells. Nucleic Acids Res 16: 2350, 1988. 
17. Bommer UA, Lazaris-Karatzas A, De Benedetti A, et al: Translational regulation of the mammalian growth-related protein P23: involvement of eIF-4E. Cell Mol Biol Res 40: 633-641, 1994.

18. Bommer UA and Thiele BJ: The translationally controlled tumour protein (TCTP). Int J Biochem Cell Biol 36: 379-385, 2004.

19. Zhang D, Li F, Weidner D, et al: Physical and functional interaction between myeloid cell leukemia 1 protein (MCL1) and Fortilin. The potential role of MCL-1 as a fortilin chaperone. J Biol Chem 277: 37430-37438, 2002.
20. Graidist P, Phongdara A and Fujise K: Antiapoptotic protein partners fortilin and MCL1 independently protect cells from 5-fluorouracil-induced cytotoxicity. J Biol Chem 279: 40868-40875, 2004.

21. Liu H, Peng HW, Cheng YS, et al: Stabilization and enhancement of the antiapoptotic activity of mcl-1 by TCTP. Mol Cell Biol 25: 3117-3126, 2005.

22. Susini L, Besse S, Duflaut D, et al: TCTP protects from apoptotic cell death by antagonizing bax function. Cell Death Differ 15: 1211-1220, 2008 